\title{
Znaczenie Pokolenia '98 dla narodowej oraz intelektualnej tożsamości Hiszpanów
}

Gdy na początku wieku XX mówi się w Europie o powstaniu nowego prądu literackiego, jakim jest modernizm, pisarze hiszpańscy formują specyficzny ruch, znany dziś pod nazwą Pokolenia '98. Do dnia dzisiejszego kwestia realnego istnienia grupy, jej faktycznych postulatów, skuteczności ich realizacji oraz wagi dla cywilizacyjnego rozwoju Hiszpanii pozostaje kontrowersyjna.

Już w roku 1908 polityk i historyk Gabriel Maura mówił o „pokoleniu klęski"", mając na myśli intelektualistów swojej epoki. Pięć lat później pisarz José Martínez Ruiz, znany pod pseudonimem Azorín, określił mianem Pokolenia '98 autorów skupionych w tak zwanej Grupo de los Tres, do której należeli poza nim Pío Baroja oraz Ramiro de Maeztu². Mentorem intelektualnym ruchu był zdecydowanie Miguel de Unamuno. Zarazem jednak mimo licznych wspólnych inicjatyw, takich jak udanie się na grób pisarza romantycznego Mariana José de Larry, który stanowił jedną z literackich inspiracji ruchu, czy utworzenie redakcji czasopisma „Juventud”, Baroja zaprzeczał przynależności do grupy, a Azorín w kilka lat po artykule wzmiankującym o Pokoleniu '98 wprost zaprzeczył jego istnieniu.

Niniejsze problemy natury formalnej należy jednak wziąć w nawias z kilku powodów. $Z$ pewnością modernizm hiszpański jest na tyle specyficzny, że wymaga dodatkowego dookreślenia, zaś termin „Pokolenie '98” dlatego wydaje się zasadny, iż w tradycji iberystyki powszechne jest nazywanie poszczególnych etapów rozwoju literatury hiszpańskiej właśnie mianem „pokoleń”. I tak pokolenie José Ortegi y Gasseta nazywamy Pokoleniem '14, a pokolenie Federico Garcíi Lorki - Pokoleniem ' $27^{3}$.

* Mgr, kamila.kruszynska@gmail.com, Uniwersytet Wrocławski, Wydział Nauk Społecznych, Instytut Filozofii, ul. Koszarowa 3/20, 51-149 Wrocław.

${ }^{1}$ F. Rico, Historia y crítica de la literatura española, t. 6, Crítica, Barcelona 1994, s. 17.

${ }^{2}$ Por. J.M. Ruiz, Clásicos y modernos, Editorial Losada S.A., Buenos Aires 1943.

${ }^{3}$ Choć z podziałem na pokolenia spotykamy się dopiero w literaturze hiszpańskiej wieku $\mathrm{XX}$, na co z pewnością miał wpływ wprowadzenie tego pojęcia przez samego Ortegę y Gasseta (El tema de nuestro tiempo, Espasa-Calpe, Madrid 1955, s. 11-19). 
Przyjmując zasadność posługiwania się terminem „Pokolenie '98”, należy zarysować jego związek z terminem „modernizm”.

Pokolenie '98 określa się niekiedy jako reakcję polityczną w obliczu klęski kraju, jaka nastąpiła w modernizmie ujmowanym jako epoka. Równie dobrze możemy jednak traktować oba zjawiska jako prądy literackie, z których jeden jest specyficznie hiszpański, mają one bowiem pewne cechy zbieżne. Co oczywiste, niektórych twórców hiszpańskiej literatury początku XX wieku można zaliczyć zarówno do autorów modernistycznych, jak i do przedstawicieli Pokolenia ' $98^{4}$. Specyfiką ich procesu twórczego były spotkania i debaty odbywające się w madryckich kawiarniach. Łączyły ich krytyczny stosunek do władzy oraz wspólnie realizowane projekty, jak redagowanie poświęconych kulturze dodatków do prasy codziennej czy ogłaszanie manifestów.

Porównując działalność zadeklarowanych modernistów i twórców Pokolenia '98 zauważamy więcej różnic niż podobieństw. Tych pierwszych poza postawą uniwersalistyczną i kosmopolityczną charakteryzowała przede wszystkim chęć ucieczki od rzeczywistości oraz problemów społecznych epoki. Autorzy tworzący w duchu ojca hispanojęzycznego modernizmu, Nikaraguańczyka Rubéna Darío, koncentrowali się na nadrzędnej wartości, jaką było dla nich piękno, oraz na doskonaleniu formy, pragnąc dostarczyć czytelnikom jak najsilniejszych przeżyć estetycznych. Przedstawiciele Pokolenia ' 98 skupiali się natomiast na pojęciu prawdy, autentyczności i realności. Ich inspiracją była głównie aktualna sytuacja polityczno-społeczna ojczyzny, ich myśl miała w sposób nieunikniony zatem zabarwienie ideologiczne. W związku z tym spośród gatunków literackich preferowali powieść, obok której nad modernistyczną poezją przeważały eseistyka oraz dramat. Głównym punktem odniesienia był dla tych twórców kryzys społeczno-polityczny, nazywany przez nich również „klęską”.

Czym jest jednak owa „klęska” w obliczu której formowała się Grupa Trzech?

Chodziło oczywiście o utratę przez Hiszpanię ostatnich kolonii - Kuby, Filipin i Puerto Rico. Symboliczny rok 1898 miał zatem oznaczać koniec Imperium Hiszpańskiego. Wielu historyków oraz pisarzy podkreśla jednak, iż koniec ów nastąpił dużo wcześniej. Kwestia ta związana jest z tak zwanym ,problemem Hiszpanii” oraz proponowanymi sposobami jego przezwyciężenia. Eugeniusz Górski, odwołując się do América Castro, uważa, iż cywilizacyjnego zacofania Hiszpanii szukać należy już w wieku XV, w którym państwo scentralizowało się pod wodzą królów katolickich jednoczących społeczeństwo pod sztandarem walki przeciw muzułmanom z jednej, a żydom - z drugiej strony. Badacz wskazuje:

\footnotetext{
${ }^{4}$ Przykładami mogą tu być twórcy tacy jak Antonio Machado (jako autor Soledades) i Ramón del Valle-Inclán (Sonatas i Światła cyganerii).
} 
muzułmanie stali się [...] główną siłą tworzącą dobra materialne, a żydzi prowadzili finanse i prace naukowe. Aby nie zostać zaliczonymi do ludzi pochodzenia żydowskiego, hiszpańscy chrześcijanie, począwszy od XVI wieku, stronili od zajęć typu intelektualnego. Z czasem stało się to główną przyczyną zacofania Półwyspu Iberyjskiego ${ }^{5}$.

Problemem podstawowym była jednak tak zwana ,izolacja” (aislamiento) Hiszpanii od Europy, którą można datować mniej więcej od roku 15806. Jak podkreśla Diego Núñez, znaczną winę za nią ponoszą katoliccy monarchowie, nieufni i podejrzliwi w stosunku do jakichkolwiek nowinek naukowych ${ }^{7}$. Hiszpania miała „dziwne szczęście do ponoszenia konsekwencji polityki antyrewolucyjnej nie przeżywając wcześniej żadnej rewolucji"8.

Poza wieloma wojnami, które osłabiły kraj (wojna o sukcesję na początku wieku XVIII, wojna o niepodległość przeciw Napoleonowi na początku wieku XIX i następujące po niej liczne wojny karlistowskie trwające z przerwami od roku 1833 do roku 1876), jako przyczyny jego słabości Górski wskazuje niewystarczajacy rozwój klasy mieszczańskiej oraz rozpowszechnioną korupcję i marazm życiowy ${ }^{9}$.

Również Rafael Núñez Florencio pisze wprost, iż Hiszpania przestała być imperium na długo przed klęską roku '98 - „'98 nie zniszczył niczego"10. Prawdą jest bowiem, że w obliczu codziennych problemów, z jakimi borykało się ówczesne społeczeństwo hiszpańskie ${ }^{11}$, utrata ostatnich kolonii miała znaczenie

${ }^{5}$ E. Górski, Idea Europy i myśl współczesna w Hiszpanii, Wydawnictwo Naukowe Scholar, Warszawa 2013, s. 12. Jednocześnie jednak badacz podkreśla, iż nieprawdą jest, iż Hiszpania nie wniosła niczego do rozwoju cywilizacyjnego. Podaje choćby przykład pierwszego użycia słowa „liberalny”, które miało miejsce w Hiszpanii w 1812 roku (por. tamże, s. 30). Podkreślić należy, że wielu myślicieli hiszpańskich było prekursorami w swych dziedzinach bądź wybitnymi ich przedstawicielami, jak wybitny myśliciel renesansowy Luis Vives czy jeden z twórców prawa naturalnego Francisco Suárez. Zapomina się też o Szkole w Salamance, której uczeni, pochłonięci tematyką duszy w kontekście hiszpańskiej konkwisty, dali podwaliny dzisiejszym prawom człowieka. Dzieło Pedra Calderóna de la Barca (jego kartezjańska refleksja na tamat rozróżnienia między snem a jawą) jest w tym kontekście równie ważne jak twórczość Cervantesa.

${ }^{6}$ Górski zwraca uwagę na znamienny fakt, iż po Napoleońskiej interwencji zmieniono w Hiszpanii (tak jak i w Rosji) rozstaw szyn kolejowych, ,,aby uniemożliwić zbyt pośpieszne, jak się obawiano «jednoczenie» kontynentu” - tamże, s. 38.

${ }^{7}$ D. Núñez, El llamado „problema de España”: mito y realidad, http://ahf-filosofia.es/wp-content/uploads/llamadoproblemaespana.pdf [dostęp: 14.07.2015].

${ }^{8}$ Tamże.

${ }^{9}$ E. Górski, dz. cyt., s. 38.

${ }^{10}$ R. Núñez Florencio, El 98 como mito, http://www.nuevarevista.net/articulos/el-98-como-mito, [dostęp: 14.07.2015].

${ }^{11}$ Krótsza niż w innych państwa europejskich długość życia, niedożywienie, niski poziom kształcenia, brak dostępu na uniwersytety dla kobiet. W 1901 r. na 19 mln mieszkańców Hiszpanii aż $12 \mathrm{mln}$ to analfabeci; obserwuje się wysoki wzrost demograficzny oraz emigrację ze wsi do 
jedynie symboliczne. Symbol ów stał się jednak punktem wyjścia dywagacji filozoficznych ówczesnych intelektualistów.

Podstawowym tematem rozważań autorów Pokolenia '98 jest zatem Hiszpania - twórcy poszukują przyczyn jej mizernej kondycji oraz drogi zapewnienia jej ponownego rozkwitu. W sposób naturalny zwracają się ku tradycji i ku regionalizmom. Są przekonani, iż w ten sposób odkryją specyfikę tego, co hiszpańskie, oraz ożywią i zjednoczą naród. Intelektualiści epoki studiują zatem historię Półwyspu oraz wracają do klasyków rodzimej literatury, szczególnym szacunkiem obdarzając Cervantesa, poetę Jorge'a Manrique'a (autora Strof na śmierć ojca), konceptystę Francisco de Quevedo oraz wspomnianego już krytyka społeczeństwa hiszpańskiego Larrę. Zachwycają się obrazami el Greco i Goi, czytają chrześcijańską mistykę. Jeśli chodzi natomiast o zagraniczne inspiracje Pokolenia '98 podkreślić trzeba znaczenie Nietzscheańskiej koncepcji nadczłowieka, teorii woli Schopenhauera oraz intuicjonizmu Bergsona.

Rozwój psychologii i psychiatrii miał wpływ na propagowanie wśród ówczesnych pisarzy metody introspekcji, która w sposób bezpośredni przełożyła się na wiarę w konieczność skupienia się na tym, co autentycznie hiszpańskie, na wydobyciu oraz kultywowaniu rodzimości.

Domykając ogólny opis ruchu roku 1898, dodać należy, iż kryzysowi na płaszczyźnie społecznej towarzyszyły osobiste kryzysy religijne, owocujące postawami skrajnymi, takimi jak ezoteryzm, agnostycyzm, satanizm. Najznamienitszym przykładem jest tu oczywiście Unamuno, który całe życie podkreślać będzie teoretyczną niewspółmierność wiary i rozumu, a kryzys religijny, który przeżył w roku 1897, był praktyczną owej niewspółmierności ilustracją.

W poszukiwaniach esencji hiszpańskości oraz czynnika jednoczącego i aktywującego naród prócz analiz historycznych i literackich powszechna wśród intelektualistów epoki staje się kontemplacja rodzimego krajobrazu. Dla Azorína jest on metaforą hiszpańskiego charakteru oraz poziomu (czy też braku) witalności narodu. „Krajobraz jest smutny i smutna jest sztuka”12 - czytamy w La voluntad. „Patrzeć na wypaloną i surową panoramę willi Toledo znaczy widzieć i rozumieć powykrzywiane i zaniepokojone postaci el Greco; tak jak patrzeć na chaszcze Ávili to rozumieć płomienne wybuchy liryczne wielkiej świętej, zaś na Kastylię całą, z jej nie kończącymi się równinami i wystrzyżonymi wzgórzami, znaczy wyczuwać inspirację, która ukształtowała naszą literaturę i naszą sztukę" ${ }^{\prime 3}$. W innym miejscu, biorąc przykład miasteczka Yecla, pisarz wspomina o słynnej hiszpańskiej abulii. Z jednej strony wychwala ludność Yecli, która była

miast. W 1887 roku Madryt liczył 12000 robotników a w roku 1900 - 90000 (przy czym kraj wciąż pozostawał głównie rolniczy). Por. J.L. Abellán, Historia crítica del pensamiento español, t. 5/II, Espasa-Calpe, Madrid 1989, s. 172.

12 J.M. Ruiz, La voluntad, Cátedra, Madrid 2014, s. 269, tłum. własne autorki.

${ }^{13}$ Tamże, s. 358, tłum. własne autorki. 
w stanie własnym nakładem sił wznieść w XIX wieku katedrę na wzór katedr średniowiecznych; z drugiej podkreśla znamienny fakt, iż katedry nie ukończono. Owo niedomknięcie, nagły zanik inicjatywy rozpatruje Azorín w kategoriach ogólnokrajowych roszczeń wystosowywanych w stosunku do władz państwowych przy jednoczesnym braku wysiłku i inicjatywy oddolnej. W trzeciej części książki znajdujemy fragment, w którym rozgoryczenie autora sięga zenitu:

Tak [...], ten duch jowialny i silny, wesoły i płodny został stracony... Te tetryczne i katolickie wsi nie są w stanie wyprodukować niczego więcej niż mężczyzn, którzy o każdej porze dnia robią to samo, oraz kobiety ubrane na czarno, które się nie myją ${ }^{14}$.

Widać zatem wyraźnie, iż stosunek przedstawicieli Pokolenia '98 do własnej ojczyzny charakteryzuje dynamika miłości i nienawiści. Kochają oni bowiem swój kraj, lud, kulturę i historię, nie będąc jednak w stanie wybaczyć rodakom apatii uniemożliwiającej cywilizacyjny rozwój.

Początek narodowej refleksji Unamuna również cechował pesymizm oraz krytyczny stosunek do rzeczywistości społecznej. W celu obudzenia sił witalnych w narodzie myśliciel pragnął ustanowić ideał hiszpańskości. Wprowadzając koncepcję intrahistorii (tego, co w dziejach stałe i niezmienne), starał się określić, czym jest hiszpańska dusza: „,[O]kazuje się, że owym intrahistorycznym substratem staje się dla Hiszpanów Kastylia z jej krajobrazem, a jej mieszkańcy stają się prawdziwym wyrazem kastycyzmu, to jest cech typowo hiszpańskich"15. Dookreślając ów kastycyzm, ustanowił Unamuno Don Kichota esencją hiszpańskości ${ }^{16}$, bohaterem narodowym oraz ideałem. Don Kichot jest zarówno symbolem wierności ideałom oraz niezłomnej walki ze złem, jak i wzorem duchowego i moralnego odrodzenia Hiszpanii oraz całej Europy.

Kwestia mesjanizmu Unamuna wiąże się ściśle z późniejszym nieco sporem między zwolennikami hispanizacji Europy a europeizacji Hiszpanii. Propozycji szukania drogi wyjścia z rozwojowego marazmu w powrocie do tradycji oraz w jej przewartościowaniu przeciwstawił się młody, lecz niesamowicie elokwentny Ortega y Gasset ${ }^{17}$. Opinie, które wygłaszał na temat ojczyzny oraz stanu jej nauki i kultury, były niebywale krytyczne i bezkompromisowe, choć nie brakowało im błyskotliwości i oryginalności. W roku 1921 y Gasset opublikował książkę España invertebrada, w której pisał między innymi, iż Hiszpania nie przeżywa kryzysu, gdyż tak naprawdę nigdy nie była u szczytu. Nazywał ojczyznę chorobą,

${ }^{14}$ Tamże, s. 274, tłum. własne autorki.

${ }^{15}$ E. Górski, Hiszpańska refleksja egzystencjalna. Studium filozofii i myśli politycznej Miguela de Unamuno, Zakład Narodowy im. Ossolińskich, Wrocław 1979, s. 86.

${ }^{16}$ Por. M. de Unamuno, En torno al casticismo, Espasa-Calpe, Madrid 1991.

${ }^{17}$ Ortega jest w zasadzie przedstawicielem dwóch pokoleń - '98 oraz '14. 
a źródła słynnej abulii swych rodaków upatrywał w zdegenerowanej krwi Wizygotów, którzy przed wiekami zasiedlali Iberię i których witalności nie sposób porównać $\mathrm{z}$ kondycją życiową Franków ${ }^{18}$.

Z owym pesymizmem Ortegi w zakresie stanu energii życiowej Hiszpanów wiązał się też jego pogląd, iż jedynie intensywna europeizacja kraju jest w stanie zaradzić sytuacji oraz że nie tylko nie istnieje ani nauka, ani filozofia hiszpańska, lecz nigdy ich nie było. W związku z tą konkluzją ogłosił, iż sam ufunduje pierwszą prawdziwą oraz godną swego miana filozofię hiszpańską - racjowitalizm.

Przeciw tej radykalnej negacji istnienia rodzimej tradycji filozoficznej opowiedział się Unamuno, twierdząc, iż ,filozofia hiszpańska rozproszona jest i rozpuszczona przede wszystkim w naszej literaturze, w naszym działaniu, w naszej mistyce" ${ }^{\prime 19}$. Pogląd ten podzielali María Zambrano oraz José Ferrater Mora, działający na terenie Stanów Zjednoczonych jeden z emigrantów epoki Franco, który w artykule Is there a Spanish philosophy? dokonał swego rodzaju podziału na filozofie teoretyczne i praktyczne, na abstrakcyjne dogmaty oraz konkretne ujęcia ludzkiej egzystencji. W kontekście tego podziału ujmował on, jak nietrudno się domyślić, ojczystą refleksję filozoficzną jako sposób bycia (czy też czynnik ów - specyficzny, jak już wiemy - sposób bycia implikujący) ${ }^{20}$.

Jakie znaczenie miała w swym czasie działalność Pokolenia '98 i jakie znaczenie ma ona dziś?

Wśród współczesnych badaczy epoki nie brak oczywiście głosów krytycznych. Pisze się o tym, iż hiszpańscy pisarze początku wieku XX byli nie tylko autorami mitów, jak tych wspomnianych powyżej, lecz że samo Pokolenie '98 stało się $\mathrm{w}$ tym samym stopniu przerysowanym mitem ${ }^{21}$. Zarzuca się bowiem jego przedstawicielom regeneracjonistyczną retorykę, skłonność do dramatyzowania oraz zbytnią krytykę przy niewystarczającej dozie faktycznego przekształcania rzeczywistości społecznej22.

Jeśli chodzi o wizję Kastylii jako esencji hiszpańskości, Carlos Moreno Hernández pisze, iż jej propagatorzy zastosowali tu prostą metonimię - za całość

${ }_{18}$ J. Ortega y Gasset, España invertebrada, Espasa-Calpe, Madrid 1964, s. 131.

${ }^{19}$ M. de Unamuno, O poczuciu tragiczności życia wśród ludzi i narodów, przeł. H. Woźniakowski, Wydawnictwo Literackie, Kraków-Wrocław 1984, s. 332. Z poglądem tym bezsprzecznie zgadza się m.in. María Zambrano, autorka koncepcji rozumu poetyckiego, będąca uczennicą zarówno Unamuno jak i Ortegi. W jednym z jej tekstów czytamy: „Cervantes mógł studiować filozofię oraz wyrazić swoją ideę, intuicję swojej woli poprzez system filozoficzny. Lecz po cóż miałby to robić? [...] Ani filozofia, ani rząd nie bazują na ludzkiej klęsce, jak jest w przypadku powieści. Dlatego to właśnie powieść musiała być dla Hiszpanów tym, czym była dla Europy filozofia" - M. Zambrano, Senderos, Anthropos, Barcelona 1989, s. 95, tłum. własne autorki.

${ }^{20}$ J. Ferrater Mora, Is there a Spanish philosophy?, http://www.ferratermora.org/essa_hispanic-review.html [dostęp: 14.07.2015].

${ }^{21}$ R. Núñez Florencio, dz. cyt.

${ }^{22}$ Tamże. 
wzięli część23 do czego Rafael Núñez Florencio dopowiada, iż jedynym realnym owocem mitologizacji Kastylii było paradoksalnie ożywienie nacjonalizmów peryferycznych, głównie katalońskiego i baskijskiego.

Odwołując się do owej krytyki, należy podkreślić, iż domeną pisarzy, o których mowa, było wyrażanie oburzenia, mitologizacja rzeczywistości i sianie zwątpienia. Jak zaznacza Górski, Unamuna nazywano wprost „burzycielem (inquietudor) sumienia epoki i kraju"24. Czyż jednak owo niepokojenie nie jest celem działania intelektualistów? Najlepszym przykładem są właśnie rozważania Unamuna dotyczące wiary. Autor Agonii chrystianizmu dywagował na tematy religijne gdyż osobiście przeżywał wewnętrzne rozdarcie między intelektualnie uzasadnionym agnostycyzmem a psychologicznie uwarunkowaną potrzebę religijną. Fakt, iż dywagacje te zgodne były z poczuciem dużej części ówczesnego wykształconego społeczeństwa, był w dużej mierze przypadkiem, czy też czynnikiem niezależnym.

Zagadnienie hiszpańskiej tożsamości i jedności narodowej jest dużo trudniejsze. Z pewnością istnieje świadomość oraz poszanowanie wspólnoty i państwowości. Prawdą jednak jest, że Hiszpania zdaje się być krajem europejskim, w którym aktualnie regionalny patriotyzm kataloński, baskijski czy andaluzyjski jest demonstrowany w sposób najbardziej energiczny, by nie powiedzieć najagresywniejszy. Współczesny hiszpański filozof Fernando Savater komentuje rodzime ruchy nacjonalistyczne w sposób następujący:

Obawiam się, iż tak jak miało to już miejsce w przeszłości (kiedy to na przykład hiszpańska wojna domowa była swego rodzaju próbą przed późniejszymi walkami II wojny światowej), Hiszpania jest dziś polem testowym atomizacji obywatelskiej oraz jej zastępowania przez tożsamości odwołujące się wyłącznie do etniczności ${ }^{25}$.

Wydaje się, że dziedzictwo Pokolenia '98 zostało w znacznej mierze zaprzepaszczone przez politykę Franco, w konsekwencji której Hiszpania po raz kolejny w dużej mierze zamknęła się na Europę. Uniwersytecka dyskusja na temat istnienia oraz specyfiki hiszpańskiej myśli filozoficznej została zawieszona, gdyż ogólnie panująca stała się scholastyka niewiele różniąca się od filozofii średniowiecznej ${ }^{26}$. Wielu intelektualistów opuściło Hiszpanię, by już nigdy do niej

${ }^{23}$ C. Moreno Hernández, Castilla, lugar común del 98, https://pendientedemigracion.ucm.es/ info/especulo/numero8/castilla.htm [dostęp: 14.07.2015].

${ }^{24}$ E. Górski, dz. cyt., s. 82.

${ }^{25}$ F. Savater, Citizens or natives?, http://www.eutopiamagazine.eu/en/fernando-savater/speakers-corner/citizens-or-natives [dostęp: 14.07.2015]. Tłum. własne autorki.

${ }^{26} \mathrm{O}$ trudnościach, jakie napotykały jeszcze do niedawna inicjatywy otwarcia zajęć poświęconych rodzimej filozofii na hiszpańskich uniwersytetach, w sposób skrupulatny donosił prof. José Luis Mora, prowadzący zajęcia z Pensamiento español na Universidad Autónoma de Madrid, w tekście wygłoszonym na konferencji w Olsztynie. Por. J.L. Mora García, Avances en el estudio 
nie powrócić. Wielu z nich, szczególnie tych, którzy udali się do Ameryki Południowej czy Środkowej, zaadaptowało się w nowej rzeczywistości, porzucając refleksję iberyjską na rzecz hispanoamerykańskiej. Również dzisiejsze postulaty poszczególnych regionów autonomicznych są w dużej mierze efektem represyjnej polityki generała.

By dokonać kolejnej mitologizacji, powiedzieć można, iż wraz ze śmiercią Miguela de Unamuno, czyli w roku 1936, Hiszpania zrobiła potężny krok w tył. Można zatem przedstawioną krytykę dokonań Pokolenia '98 traktować jako krytykę tak naprawdę nie skierowaną w Pokolenie '98. Tak jak i Polaków, charakteryzuje również i ówczesnych Hiszpanów duża doza kontestacji, sceptycyzmu, nieufności i autokrytyki. W porównaniu jednak ze swymi rodakami z początku zeszłego wieku nieporównywalnie zyskali oni na samoświadomości oraz poczuciu wartości własnej kultury, którą da się mimo wielu głosów sprzeciwu ujmować jako ogólnonarodową. Bez cennego wysiłku Pokolenia Klęski z pewnością inna byłby dziś dusza (by użyć retoryki Unamuna) hiszpańska, o ile byłaby hiszpańską.

\section{Bibliografia}

Abellán José Luis, Historia crítica del pensamiento español, t. 5/II, Espasa-Calpe, Madrid 1989.

Ferrater Mora José, Is there a Spanish philosophy?, http://www.ferratermora.org/essa_hispanicreview.html [dostęp: 14.07.2015].

Górski Eugeniusz, Hiszpańska refleksja egzystencjalna. Studium filozofii i myśli politycznej Miguela de Unamuno, Zakład Narodowy im. Ossolińskich, Wrocław 1979.

Górski Eugeniusz, Idea Europy i myśl współczesna w Hiszpanii, Wydawnictwo Naukowe Scholar, Warszawa 2013.

Mora García José Luis, Avances en el estudio de la filosofía hispánica, w: Z myśli hiszpańskiej i iberamerykańskiej. Filozofia - literatura - mistyka. María Zambrano: un pensamiento en el orden del tiempo, red. M. Jagłowski, D. Sepczyńska, Instytut Filozofii Uniwersytetu Warmińsko-Mazurskiego, Olsztyn 2006, s. 15-30.

Moreno Hernández Carlos, Castilla, lugar común del 98, https://pendientedemigracion.ucm.es/ info/especulo/numero8/castilla.htm [dostęp: 14.07.2015].

Núñez Diego, El llamado "problema de España”: mito y realidad, http://ahf-filosofia.es/wp-content/uploads/llamadoproblemaespana.pdf [dostęp: 14.07.2015].

Núñez Florencio Rafael, El 98 como mito, http://www.nuevarevista.net/articulos/el-98-como-mito [dostęp: 14.07.2015].

Ortega y Gasset José, El tema de nuestro tiempo, Espasa-Calpe, Madrid 1955.

Ortega y Gasset José, España invertebrada, Espasa-Calpe, Madrid 1964.

Rico Francisco, Historia y crítica de la literatura española, t. 6, Crítica, Barcelona 1994.

Ruiz José Martínez, Clásicos y modernos, Editorial Losada, Buenos Aires 1943.

de la filosofía hispánica, w: Z myśli hiszpańskiej i iberamerykańskiej. Filozofia-literatura - mistyka, red. M. Jagłowski, D. Sepczyńska, Instytut Filozofii Uniwersytetu Warmińsko-Mazurskiego, Olsztyn 2006, s. 13-30. 
Ruiz José Martínez, La voluntad, Cátedra, Madrid 2014.

Savater Fernando, Citizens or natives?, http://www.eutopiamagazine.eu/en/fernando-savater/speakers-corner/citizens-or-natives [dostęp: 14.07.2015].

Unamuno de Miguel, En torno al casticismo, Espasa-Calpe, Madrid 1991.

Unamuno de Miguel, O poczuciu tragiczności życia wśród ludzi i narodów, przeł. H. Woźniakowski, Wydawnictwo Literackie, Kraków-Wrocław 1984.

Zambrano María, Senderos, Anthropos, Barcelona 1989.

Kamila Kruszyńska

\section{Generation '98 and its importance for the national and intellectual identity of Spaniards}

\section{(Summary)}

The article presents the characteristics of Spanish modernism. The author points to a group of writers known as Generation '98, whose shared characteristic was their focus on the criticism of the socio-political situation of their country in the late nineteenth and early twentieth century. The key representatives of the group are: Miguel de Unamuno, José Martínez Ruiz (Azorín), Pío Baroja, Ramiro de Maeztu, and Ramón del Valle-Inclán. The first section of the paper outlines the specific qualities of the literary output and attitudes of the Generation '98 writers, distinct from modernism as such. The second part focuses on the attitude of thinkers to Spain and Spanishness, as well as intellectual consequences thereof. The final part presents a critique of that trend and its interpretation.

Słowa kluczowe: Pokolenie '98; Hiszpania; modernizm; tożsamość narodowa; krytyka społeczna; kryzys

Keywords: Generation '98; Spain; modernism; national identity; social criticism; crisis 